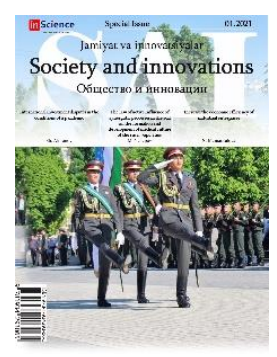

\title{
Historical origins and the role of the upper house of parliament in states with a bicameral parliamentary system
}

\section{Laylo ASLONOVA ${ }^{1}$}

Tashkent State University of Law

\begin{tabular}{l} 
ARTICLE INFO \\
\hline Article history: \\
Received January 2021 \\
Received in revised form \\
15 January 2021 \\
Accepted 20 January 2021 \\
Available online \\
10 February 2021 \\
\hline
\end{tabular}

\section{Keywords:}

Bicameralism

Upper house

Monocameralism

Parliament

Tricameral parliament

\begin{abstract}
This article analyzes the legal study of bicameralism as a phenomenon of modern parliamentarism. The evolution of functions, powers and methods of activity of bicameral parliaments is studied, in particular, the historical and political context of the creation of the upper chambers of parliament at various stages of state and legal construction is indicated. Also, a comparative analysis of historical and theoretical studies of the role of the upper house of parliaments was carried out.
\end{abstract}

2181-1415/C) 2021 in Science LLC.

This is an open access article under the Attribution 4.0 International (CC BY 4.0) license (https://creativecommons.org/licenses/by/4.0/deed.ru)

\section{Бикамерал парламентли давлатларда парламент юқори палатасининг тарихий келиб чиқиши ва роли}

\begin{tabular}{l}
\hline Калит сўзлар: \\
Бикамерализм \\
Юқори палата \\
Монокамерализм \\
Парламент \\
Уч палатали парламент.
\end{tabular}

Калит сўзлар:

Бикамерализм

Монокамерализм

Уч палатали парламент.

\begin{abstract}
АННОТАЦИЯ
Ушбу мақолада замонавий парламентаризм феномени сифатида бикамерализмнинг хуқуқий асослари тахлил қилинган. Икки палатали парламентларнинг функциялари, ваколатлари ва фаолиятининг эволюцияси ўрганилган, хусусан, давлат ва хуқуқий қурилишнинг турли босқичларида парламентнинг юқори палаталарини ташкил этишнинг тарихий ва сиёсий контексти кўрсатилган. Шунингдек, парламентлар юқори палатасининг роли хақидаги тарихий ва назарий тадқиқотларнинг қиёсий тахлили акс эттирилган.
\end{abstract}

\footnotetext{
${ }^{1}$ Lecturer, Tashkent State University of Law Tashkent, Tashkent, Uzbekistan

E-mail: Leyla aslanova1221@mail.ru
} 


\section{Историческое происхождение и роль верхней палаты парламента в государствах с бикамеральной парламентской системой}

Ключевые слова:
Бикамерализм
Верхняя палата
Монокамерализм
Парламент
Трехпалатный парламент

\begin{abstract}
АННОТАЦИЯ
В данной статье анализировано юридическое исследование двухпалатности как явления современного парламентаризма. Изучено эволюция функций, полномочий и методов деятельности двухпалатных парламентов, в частности, обозначается исторический и политический контекст создания верхних палат парламента на различных этапах государственного и правового строительства. Также, проведен сравнительный анализ исторических и теоретических исследований роли верхней палаты парламентов.
\end{abstract}

Over the past few years, the proportion of unicameral parliaments has increased, although in the 19th century almost all existing legislative institutions had a bicameral structure. In general, in the last quarter of the XX century. There was a steady tendency towards an increase in the proportion of unicameral parliaments among all national parliaments of the world: in 1976 the share of bicameral parliaments was $46 \%$ (26 out of 56) [4], in $1986-34 \%$ (28 out of 83) [7], in October 1996-33\% (59 out of 178) [5]. At the same time, in some countries at the turn of the XX and XXI centuries there was a transition from uniqueness to bicameralism. So, in 1995 the parliament of Kazakhstan became bicameral, in 1996, the parliaments of the Czech Republic and Belarus, as a result of the reform of 2002-2004, the parliament of Uzbekistan and in some states during this period, soon after the introduction of bicameralism, they are ready to abandon it. For example, in Kyrgyzstan, from 1995 to 2005, a bicameral parliament, the Jogorku Kenesh, worked for two convocations, and, in accordance with the results of the referendum of February 2, 2003, the Jogorku Kenesh became unicameral in 2005. [8]

Today, in 192 states of the world, according to the statistics of the Interparliamentary Union, there are 80 bicameral (41.6\%) and 112 one-chamber (58.3\%) parliaments functioned. [6] In this regard, it is inappropriate to talk about the trend of bicameralism, as well as "waves of monocameralism", although the importance of the upper chambers in the context of different types of parliamentarism is one of the areas of research.

In history, there are not only unicameral and bicameral parliaments, but also tricameral parliaments. However, the presence of more than two chambers in parliament is an exception to the general rule. An example of a three-chamber parliament is the Chinese three-chamber parliament, which functioned since 1947. It consisted of the National Assembly, the Legislative Yuan, and the Control of the Yuan. additionally, in history there were several examples of threechamber parliaments: South Africa's parliament, in accordance with the 1983 constitution, included three chambers; The First French Empire or Yugoslavia - in accordance with the 1974 constitution, the parliaments of the republics that are part of the country were three-chamber.

Indeed, the structure of parliament (unique, bicameral, or even tricameral) affects the order of its work, increasing or decreasing the efficiency of its activities, but also on the policy pursued by the legislature, and on the nature of the institution's relationship with other public authorities. Therefore, the issues of optimizing the structure of the parliament, including the 
establishment of the number of chambers in the parliament, are at the center of attention when establishing any parliament. At the same time, the historically indicated issues appeared simultaneously with the emergence of the parliaments themselves and, most likely, will exist as long as modern parliaments exist.

The first substantiations of the need for the functioning of the upper chambers date back to the era of the emergence of the theory of separation of powers. The need for such chambers was due to the weakness of parliaments in the system of checks and balances due to the falling of representative institutions into dependence on the executive branch or the risk of obtaining a significant part of mandates by representatives of the ruling power. Representatives of the liberal tradition (J.J. Rousseau, I. Bentham, B. Constant, J. Locke, C. Montesquieu) considered bicameralism as one of the institutional mechanisms to ensure the principle of separation of powers [2].

Another important argument in favor of choosing a model of parliamentary structure was the issue of the territorial structure of the state. It is believed that a multi-chamber structure of parliament is most typical for federal states, and a single-chamber structure for unitary or countries undergoing unstable or transitional periods.

If you look at history, the upper chamber in medieval estate-representative institutions did not need to be created. It existed as if by virtue of the natural order of things. Persons who were members of the upper chamber of the medieval estate-representative institution in terms of their estate-social status and property status were not only entitled, but also obliged to help the monarch in governing the state. This is what they did, and it was in this capacity that they participated in the work of the estate-representative institution. This kind of sincerity of the participation of these persons in the work of estate-representative institutions did not require any explanation. All this fully corresponded to the basic values and basic ideas of the political consciousness of the Middle Ages.

With the passage of time, entrepreneurs included in the growing market economy (in some countries a part of the middle and small nobility was in their midst) increasingly demanded legal and political changes. Naturally, the upper fees (in those countries where the estate-representative institutions continued to convene), consisting of persons who formed the feudal elite, were in opposition to bourgeois innovations. Therefore, by the natural-historical course of events at the dawn of modern parliamentarism, the upper chambers began to play a conservative role.

However, it is worth emphasizing: what was perceived as a natural and logical phenomenon in the era of feudalism turned into unnatural for a significant part of the people of modern times. The concept of popular sovereignty is replacing the concept of the concentration of sovereignty in the monarch, and the proclamation of human rights and freedoms is replacing the consolidation of privileges, liberties and encumbrances for a person as a member of an estate group, as a bearer of individually bestowed advantages over others. In such conditions, the upper chamber of the representative body already looks superfluous, because all people participate on an equal footing in elections to the parliament, which acts on behalf of and on behalf of the sovereign people.

In some countries, the preservation of the upper house has become a certain compromise between the supporters of the new political and economic system and the forces that sought to preserve at least some remnants of the old regime. This was the case, in particular, in England, when, after the restoration of the Stewart rule, the bicameral structure of parliament was restored. The upper house of the English parliament (and it became a model for many 
parliaments that appeared later) was a conservative body capable of restraining the initiatives of the lower house, the creation of such chambers began to be seen as an effective way to curb any unwanted transformations. In France, the first parliament, created under the Constitution of 1791, was unicameral, and then, after a series of revolutionary and counter-revolutionary coups, when the restoration of the Bourbon dynasty (1814 and 1815) took place, they passed to a bicameral parliament.

Be that as it may, however in some countries the upper house was initially viewed as a kind of restraining the democratic aspirations of the lower house in those cases when the country's leadership was reluctant to include parliament in the system of state bodies and perceived this as a certain concession under the pressure of the revolutionary movement if impossible cope with such a movement by forceful methods. Therefore, some modern scholars recognize that in unitary states the nature of the second house in some cases reflects the conscious or unconscious desire of those who created the constitution to moderate the democratic offensive spirit of the first house with the help of a more conservative part of the representative body. [3] In other words, even in the XX-XXI centuries, when in Europe it is no longer a question of preserving any political representation of any remnants of feudalism, the upper house of parliament in a unitary state is viewed as a starting point that restrains democratic aspirations. Guided by the approach according to which the second chamber, most often called the upper one, is a constraining one for progressive transformations, in the XX century many unitary states, consistently implementing the democratization of public administration, abandoned bicameralism: for example, New Zealand in 1950, Denmark in 1953, Sweden in 1969. The 1975 Greek Constitution provides for a unicameral parliament.

French liberal thinker of the 19th century B. Constant saw in the upper house a separate branch of power, distinguishing it from the legislative power, which belongs to the lower house of parliament [1]. He believed that such a chamber, expressing the interests of the landed aristocracy, is a completely special type of representation, and therefore it finds its place in the system of division of power. In addition, in the system of division of power, its individual branches are not only independent, but also interact and interdependent.

B. Constant's idea of the importance of the upper house of parliament in the system of separation of powers was continued by another French scientist A. Esmen. According to his point of view, an important means of ensuring the balance of the branches of government is the bicameral structure of parliaments, which allows the government to rely on one of the chambers in case of conflict with the other [9]. However, if we continue such reasoning, then the conclusion suggests itself that the bicameral structure of parliament strengthens the executive branch, upsetting the balance of branches of government in favor of the executive branch.

So, as we can see, the bicameral system remains in the modern world and arouses unflagging interest among both theorists and practitioners. The powers of the upper chambers of today's parliaments have changed over time, as is the role in parliamentarism in general.

\section{References}

1. Constant B. Lecoursdela politique constitutionnelle. P., 1836.

2. Filippova N. A. Bikameralizm v postsovetskikh gosudarstvakh: tendentsii razvitiya instituta // POLITEHKS. 2005. No 3. S. 37-48.

3. Fusiler R. Les monarchies parlementaires .Études sur les systèmes de gouvernement (Suéde, Norvège, Danemark, Belgique, Pays-Bas, Luxembourg). P., 1960, p. $29 \mathrm{ff}$.

4. Herman V., Mendel F. Parliaments of the World: a Reference Compendium. L., 1976 
5. Inter-Parliamentary Union. Parline Database, 1996.

6. Inter-Parliamentary Union. Parline Database, 2020.

7. Parliaments of the World: a Comparative Reference Compendium. Aldershot, 1986

8. А.С. Автономов. 2013. Истоки и смысл двухпалатности парламентов. Вісник маріупольського державного університету серія: право (5). 35-42

9. Эсмен А. Общие основания конституционного права. СПб., 1909, с. 81. 